\title{
Model pembelajaran students team achievement division untuk meningkatkan keaktifan dan hasil belajar IPS
}

\author{
oleh \\ Sumiyati \\ SMP N 4 Surakarta \\ sumiyatibaik1993@gmail.com
}

received: 23-02-2021

revised: 01-03-2021

accepted: o2-03-2021

\begin{abstract}
Abstrak
Tujuan penelitian untuk mengetahui (1) upaya meningkatkan keaktifan belajar dan hasil belajar peserta didik SMP dengan model pembelajaran kooperatif students team achievement division (STAD), (2) peningkatan keaktifan belajar dan hasil belajar peserta didikSMP dengan model pembelajaran tersebut. Penelitian menggunakan metode penelitian tindakan kelas, dengan subjek penelitian peserta didik kelas VII D SMP Negeri 14 Surakarta berjumlah 32 orang. Teknik pengumpulan data menggunakan observasi, tes, dan dokumentasi. Teknik analisis data yang digunakan teknik analisis data kualitatif model Miles \& Huberman. Hasil penelitian menunjukkan bahwa: (1) model pembelajaran STAD dilakukan dengan langkahlangkah: pembagian kelompok, menentukan skor awal, pemaparan materi, mengerjakan kuis, menghitung skor individu dan kelompok, merekognisi prestasi kelompok; (2) model pembelajaran STAD mampu meningkatkan keaktifan belajar sebesar 15\% dan hasil belajar IPS sebesar 8,0.
\end{abstract}

Kata Kunci: Student Team Achievement Division, keaktifan, hasil belajar IPS

\begin{abstract}
The research objective was to find out (1) improvement learning activeness and outcomes of junior high school students with student team achievement division (STAD) model, and (2) increasing learning activeness and outcomes of junior high school students by the model. The research conducted using classroom action research, with subject of students of class VII D SMP Negeri 14 Surakarta, totaling 32 people. Data collection techniques using observation, tests, and documentation. The technique of data analysis used qualitative data analysis technique of Miles \& Huberman model. The results showed that: (1) the STAD learning model was carried out with the following steps: group division, determining initial scores, building groups, material exposure, group study, taking quizzes, calculating individual and group scores, recognizing group achievement, and returns quiz results with an emphasis on group discussion, and individual skills; (2) the STAD learning model was able to increase learning activeness $15 \%$ and social studies learning outcomes 8.o.
\end{abstract}

Keywords: Student Teams Achievement Division, activeness, social studies learning outcomes 


\section{Pendahuluan}

Perkembangan sosial dan budaya yang semakin kompleks terutama pada era globalisasi sekarang menuntut paradigma baru pendidikan yang menekankan pengembangan manusia yang mampu beradaptasi dengan perubahan secara kreatif, serta mampu memecahkan permasalahan yang dihadapi. Dewey (Ornstein dan Levis, 1989: 139) mengemukakan education is that reconstruction or reorganization of experience and which increases ability to direct the course of subsequent experience. Pendidikan harus menyiapkan generasi abad ke-21 yang unggul, berdaya saing tinggi dan mampu bekerjasama guna mencapai kemakmuran bagi masyarakat, di samping itu pengembangan moral dan karakter manusia Indonesia yang tangguh hanya dapat dicapai melalui pendidikan yang berkualitas. Herbart (Nergney dan Herbert, 2001: 42) yang menyatakan bahwa ... primary goal of education was to respect a child's individuality while conveying the discipline and consistency necessary to develop moral strength of character.

Dewasa ini pendidikan nasional dihadapkan pada empat krisis pokok, yakni kuantitas, relevansi atau efisiensi eksternal, elitisme, dan manajemen. Tilaar (2008) menyatakan bahwa ada tujuh masalah pokok dalam sistem pendidikan nasional, yaitu: menurunnya akhlak dan moral peserta didik; pemerataan kesempatan belajar; masih rendahnya efisiensi internal sistem pendidikan; dan status kelembagaan, menejemen pendidikan yang tidak sejalan dengan pembangunan nasional; sumber daya manusia yang belum profesional. Masalah lainnya adalah perencanaan dan implementasi program-program peningkatan kualitas secara sistematik sehingga seakan-akan satuan pendidikan berjalan sendiri-sendiri.

Pendidikan nasional sebagai wahana sosialisasi dan pembudayaan warisan budaya, nilai-nilai kebudayaan nasional, dan nilai-nilai global yang dikuasai oleh iptek dan persaingan global, belum sepenuhnya terlaksana dengan baik. Pendidikan nasional yang sudah dilaksanakan secara merata belum berhasil mengembangkan insan pembangunan yang mampu mengolah dan mengelola sumber daya alam, mengelola modal, mengembangkan teknologi, menghasilkan komoditas yang mutunya mampu bersaing dan mampu mengembangkan sistem perdagangan, pendidikan nasional belum sepenuhnya mampu mengembangkan manusia Indonesia yang religius, intelektual, berakhlak, berwatak ksatria, serta berjiwa patriotik.

Pembaharuan pendidikan untuk meningkatkan kualitas pendidikan terus 
dilakukan secara inovatif dan kreatif, salah satunya dengan peninjauan dan perbaikan kurikulum. Kementerian Pendidikan dan Kebudayaan RI (2016) tentang Standar Proses Pendidikan dasar dan menengah telah menjelaskan bahwa pembelajaran dalam kurikulum 2013 perlu diterapkan pembelajaran berbasis penelitian. Untuk mendorong kemampuan peserta didikmenghasilkan karya konstektual, maka guru disarankan untuk menggunakan pendekatan pembelajaran yang menghasilkan karya berbasis pemecahan masalah (project-based learning). Pembelajaran mengunakan pendekatan saintifik, discovery learning, inquiry learning, dan projet based learning merupakan pendekatan pembelajaran yang berpusat pada peserta didik dan guru adalah sebagai fasilitator, guru sebagai fasilitator memiliki peranan untuk menyumbangkan ide-ide terkait pembelajaran.

Pembelajaran yang baik adalah pembelajaran yang telah direncanakan sedemikian rupa dengan model dan media pembelajaran yang mendukung. Pemilihan model pembelajaran dengan demikian memerlukan analisis situasi yang tepat karena akan berdampak pada kualitas pembelajaran di dalam kelas. Hanifah dan Wulandari (2018: 63) menyatakan bahwa pembelajaran yang berkulitas dapat diketahui dari interaksi antara guru guru dengan peserta didik yang menghasilkan perubahanperubahan perilaku pada peserta didik terkait suatu materi pembelajaran. Suparmini, dkk. (2015: 123) menyatakan bahwa pembelajaran yang dilakukan di dalam kelas seharusnya mampu mengantarkan peserta didik untuk mencapai kompetensi dasar dan kompetensi inti sebagaimana telah dirancang dalam rencana pelaksanaan pembelajaran.

Pembelajaran IPS di sekolah menengah pertama perlu lebih menekankan standar proses yang berorientasi pada upaya meningkatkan interaksi dan komunikasi sehingga tujuan pembelajaran dapat dicapai dengan maksimal. Kualitas kemanusiaan peserta didik dapat ditingkatkan melalui proses interaksi dan komunikasi yang intensif sehingga sekolah sebagai wahana humanisasi menjadi dapat direalisasi. Sudrajat, dkk. (2020: 51) mengemukakan bahwa ... the humanistic approach is concerned with making connections with people in other fields, with practice in schools, and with other human services. Often it becomes a study of the foundations of the helping professions as a whole and seeks to identify generic knowledge and competence underlying those professions.

Namun dalam pelaksanaannya di lapangan terdapat kendala-kendala, sehingga tujuan untuk meningkatkan kualitas pembelajaran belum dapat tecapai. Berdasarkan hasil observasi dan wawancara yang dilakukan peneliti pada kelas VII D dan 
guru pengampu mata pelajaran kelas VII D IPS SMP Negeri 14 Surakarta ada beberapa permasalahan yang ditemukan dalam kegiatan pembelajaran IPS. Permasalahan utama yang ditemukan peneliti adalah rendahnya tingkat keaktifan belajar dan hasil belajar peserta didik. Dalam kegiatan pembelajran IPS peserta didik lebih banyak diam, berbisik-bisik dengan sesamanya, atau malah tidak memperhatikan sama sekali. Salah satu indikator keberhasilan pembelajaran adalah terbangunnya interaksi di dalam kelas yang mengantarkan peserta didik untuk mencapai kompetensi yang telah ditetapkan. Salah satu model pembelajaran yang memenuhi kriteria tersebut adalah paradigma pembelajaran kooperatif model STAD

Syamsu, dkk. (2019) menyatakan bahwa model pembelajaran STAD menekankan pada aktivitas dan interaksi antara siswa untuk saling membantu dalam menguasai materi pelajaran, guna mencapai tujuan yang diharapkan, siswa di tempatkan dalam tim belajar agar bekerja sama dalam kelompok untuk menyelesaikan tugas yang diberikan oleh guru. Model pembelajaran STAD merupakan salah satu strategi pembelajaran kooperatif yang di dalamnya terdapat beberapa kelompok kecil siswa dengan level kemampuan akademik yang berbedabeda saling bekerja sama untuk menyelesaikan tujuan pembelajaran.

Slavin (2011: 4) mendefinisikan pembelajaran kooperatif sebagai pembelajaran yang dilaksanakan secara berkelompok, peserta didik dalam satu kelas dijadikan kelompok-kelompok kecil yang terdiri dari 4 sampai 5 peserta didik untuk memahami konsep yang diberikan oleh guru. Pembelajaran kooperatif adalah rangkaian kegiatan belajar yang dilakukan oleh peserta didik dalam kelompok-kelompok tertentu untuk mencapai tujuan pembelajaran yang telah dirumuskan. Ada empat unsur dalam pembelajaran kooperatif, yaitu adanya peserta, aturan, upaya belajar setiap anggota kelompok, dan tujuan yang akan dicapai. Nurmayanti, dkk. (2014) menyatakan bahwa peranan model pembelajaran dapat digunakan sebagai salah satu alternatif untuk meningkatkan motivasi belajar siswa. Model pembelajaran kooperatif (cooperative learning) merupakan model yang dapat digunakan sebagai alternative untuk meningkatkan motivasi belajar siswa. Pembelajaran kooperatif merupakan pembelajaran kelompok dengan jumlah peserta didik 2-5 orang dengan gagasan untuk saling memotivasi antar anggota untuk saling membantu agar tercapainnya suatu tujuan pembelajaran yang maksimal.

Isjoni (2012: 23) mengemukakan bahwa pembelajaran kooperatif adalah suatu model pembelajaran yang saat ini banyak digunakan untuk mewujudkan kegiatan belajar mengajar yang berpusat pada peserta didik (student oriented), terutama untuk 
mengatasi permasalahan yang ditemukan guru dengan mengaktifkan peserta didik yang tidak dapat berkerjasama dengan peserta didik lain, peserta didik yang agresif dan tidak peduli dengan orang lain dan lingkungan sekitar. Tipe-tipe model pembelajaran kooperatif terdiri dari STAD (Student Team Achievement Division), TGT (Team Game Tournament), TAI (Team Assisted Individualization), dan CIRC (Cooperative Integrated Reading and Composition). Slavin (2011: 143) mengungkapkan bahwa salah satu model pembelajaran kooperatif yang paling sederhana adalah tipe Student Teams Achievement Divisions (STAD), dimana model tersebut paling tepat untuk permulaan bagi guru yang baru menggunakan pendekatan kooperatif. Isjoni (2012: 74) mengemukakan bahwa pembelajaran kooperatif tipe STAD merupakan salah satu pembelajaran kooperatif yang menekankan pembelajaran pada adanya aktivitas dan interaksi diantara peserta didik untuk saling memotivasi dan saling membantu dalam menguasai materi pelajaran guna mencapai hasil belajar yang maksimal.

Dalam konsep pembelajaran STAD juga berlangsung peer teaching dimana peserta didik belajar dari sesama teman sehingga dapat berlangsung pembelajaran yang menyenangkan dan bermakna. Gambaran model pembelajaran STAD yang mengembangkan kerjasama untuk memecahkan masalah disajikan dalam gambar berikut.

Gambar 1.

Konsep dasar pembelajaran STAD

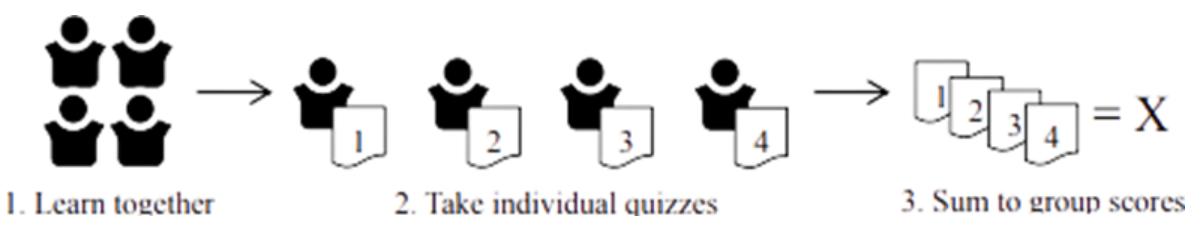

Habsiah, dkk. (2017) menyebutkan bahwa model pembelajaran STAD dapat meningkatkan karakter peserta didik. Efforts to improve the character of tolerance can be done through cooperative learning model Student Team Achievement Division (STAD) because this method is a learning method that emphasizes the process of how students gain knowledge and new insights that is by way of cooperation. Dalam penelitiannya di SMP Negeri 29 Bandung, Habsiah, dkk. (2017) menemukan bahwa 
terdapat peningkatan yang signifikan dalam sikap toleransi peserta didik setelah guru melaksanakan pembelajaran dengan model STAD.

National Council for social Studies mendefinisikan IPS sebagai studi ilmu-ilmu sosial dan humaniora yang diintegrasikan untuk tujuan membentuk kewarganegaraan. IPS di sekolah menjadi suatu studi secara sistematik dalam berbagai disiplin ilmu seperti antropologi, arkeologi, ekonomi, geografi, sejarah, hukum, filsafat, politik, psikologi, agama, dan sosiologi, sebagaimana yang ada dalam ilmu-ilmu humaniora bahkan termasuk matematika dan ilmu-ilmu alam dapat menjadi aspek dalam IPS (Supardi, 2011: 182). Pendidikan IPS menekankan pada keterampilan peserta didik dalam memecahkan masalah mulai dari lingkup diri sampai pada masalah yang kompleks. Pendidikan IPS menuntut untuk berpikir kritis dalam memecahkan masalah sosial tersebut sehingga akan bisa menyelesaikan suatu masalah baik pada lingkup kecil yaitu diri sendiri maupun masalah pada lingkup besar yaitu masyarakat.

Sudrajat, dkk. (2020: 48) menyebutkan bahwa social studies expected to be one of the subjects that develop humanism in education. As a subject that is full of value, it should be the front line for developing the humanist values in society. It corresponds to the foundation of social studies on charity, provided by the fundamental ideas for determining the ideal human characteristics as the goal of the educational process. Dalam konteks demikian maka sudah sewajarnya apabila guru IPS serta dosen dan peneliti memikirkan strategi pembelajaran yang sesuai untuk menjadikan IPS sebagai sebuah mata pelajaran yang mampu menjadikan peserta didik sebagai manusia seutuhnya serta menjadi warga negara yang baik. Penelitian perlu dilakukan agar ke depan IPS mampu berperan sebagai mata pelajaran moral, etika dan kewarganegaraan yang efektif dan efisien.

Pembelajaran IPS dengan kurikulum 2013 adalah sejalan dengan peningkatan kompetensi peserta didik terutama berhubungan dengan keaktifan belajar yang selanjutnya akan berpengaruh pada hasil belajarnya. Namun perlu dilakukan pemilihan model pembelajaran yang sesuai dengan berbagai karakteristik peserta didik, lingkungan belajar, serta sarana dan prasarana yang tersedia di sekolah. Model pembelajaran STAD merupakan salah satu model yang perlu dipertimbangkan oleh para guru untuk memperbaiki kualitas pembelajaran IPS di sekolah menengah pertama. Implementasi STAD pada pembelajaran IPS di SMP Negeri 14 Surakarta merupakan sebuah kebutuhan mengingat kondisi kelas VII D perlu mendapat perlakuan segera agar keaktifan dan hasil belajar peserta didik dapat dicapai dengan 
maksimal. Penerapan model-model pembelajaran sebagai upaya peningkatan kualitas pembelajaran IPS perlu mendapat apresiasi serta dipublikasikan agar dapat dijadikan contoh atau model bagi pembelajaran IPS di sekolah lain sehingga hasil penelitian memberikan nurturant impact terhadap dunia pendidikan secara lebih luas.

\section{Metode Penelitian}

Penelitian dilaksanakan dengan metode Penelitian Tindakan Kelas (PTK) yang dilaksanakan secara kolaboratif antara guru-guru yang mengampu mata pelajaran IPS di SMP Negeri 14 Surakarta yang berjumlah 3 orang. Model PTK yang dipilih adalah model Kemmis dan Taggart (1999) dengan kegiatan terdiri dari: perencanaan, pelaksanaan, observasi, dan refleksi. Namun sebelum melakukan perencanaan bersama dengan tim guru IPS, analisis data sekunder telah dilakukan untuk membuat gambaran dari kelas VII D secara keseluruhan.

Waktu penelitian dimulai dari bulan Maret sampai dengan Mei 2019 dengan subjek peserta didik VII D SMP Negeri 14 Surakarta yang berjumlah 32 orang. Metode dan instrumen yang digunakan yaitu observasi, tes, dan dokumentasi. Teknik analisis data yang digunakan adalah teknik analisis data kualitatif model Miles dan Huberman (1994) yang meliputi data collection, data display, data reduction dan conclusion. Implementasi model pembelajaran kooperatif tipe students team achievement divisions (STAD) dapat dinyatakan meningkatkan keaktifan belajar apabila 70\% peserta didik terlibat aktif dalam mengikuti kegiatan pembelajaran. Sedangkan hasil belajar apabila sekitar $75 \%$ dari total keseluruhan peserta didik telah memenuhi nilai KKM mata pelajaran IPS yaitu 75 sehingga dianggap telah berhasil dalam meningkatkan keaktifan dan hasil belajar IPS dengan baik.

\section{Hasil dan Pembahasan}

Pelaksanaan penelitian diawali dengan diskusi dan refleksi dengan semua guru IPS di SMP Negeri 14 Surakarta terkait kelas yang akan menjadi objek penelitian. Guru pengampu mata pelajaran IPS merefleksikan hasil pengamatan yang diperoleh selama memfasilitasi pembelajaran di semua kelas. Aspek utama yang menjadi perhatian adalah apakah hasil belajar IPS telah sesuai dengan harapan ataukah belum. Akhirnya ditentukan bahwa kelas VII D merupakan kelas yang perlu mendapat perlakuan khusus agar keaktifan dan hasil belajarnya meningkat. Peneliti bersama dengan guru lainnya kemudian mendiskusikan terkait rancangan kegiatan yang akan dilakukan pada pada siklus 1. 
Tim peneliti merumuskan bahwa perlakuan yang tepat untuk mengatasi permasalahan pada kelas tersebut adalah dengan menerapkan metode pembelajaran student team achievement division yang memiliki berbagai kelebihan. Di samping itu metode tersebut juga menuntut peserta didik untuk terus beraktivitas secara berkolompok sehingga juga menambah kreativitas dan aktivitas pembelajaran IPS. Tindakan siklus I dilaksanakan sebanyak dua kali pertemuan. Pertemuan pertama dilaksanakan pada hari Selasa, 9 April 2019 dan pertemuan kedua pada hari Kamis 11 April 2019. Dengan materi "Masuknya Kebudayaan Hindu Budha di Indonesia”. Hasil pengamatan terhadap peserta didik secara umum pada siklus I adalah peserta didik masih belum terbiasa dengan model pembelajaran seperti ini yang mana kekompakan kelompok dibutuhkan tetapi memiliki kewajiban individu yang sama, masih ada kelompok yang hanya beberapa anggota yang ikut aktif seperti model pembelajaran diskusi biasa. Ketika kuis diberikan masih ada beberapa peserta didik yang mengerjakan dengan berdiskusi sehingga tidak sesuai dengan peraturan dari model pembelajaran ini yang mana peserta didik dituntut untuk mengerjakan secara individu yang mana akan berpengaruh pada nilai kelompoknya.

Hasil pengamatan pada siklus 1 yang dilakukan pada saat proses pembelajaran terhadap guru adalah kurangnya penjelasan tentang model pembelajaran yang akan digunakan dalam pembelajaran sehingga peserta didik masih terlihat bingung untuk mengikuti langkah-langkah pembelajaran yang telah dijelaskan dengan operasional. Motivasi yang diberikan guru kepada peserta didik kurang berpengaruh terhadap kinerja pembelajaran. Hal ini barangkali karena siswa belum terbiasa menggunakan model pembelajaran STAD, sehingga mereka merasa canggung dan tidak enjoy dalam belajar. Di samping itu barangkali guru juga menghadapi kendala dalam merancang instruksi, dimana kurang operasional dalam merancang tempat duduk dan pengaturan kelompok, sehingga membuat peserta didik tidak leluasa dalam kegiatan belajar. Motivasi bernada positif seperti adanya penambahan nilai yang akan diberikan ketika memberikan pendapat dan bertanya belum mampu mendorong peserta didik untuk terlibat secara aktif dengan mengajukan pertanyaan atau menjawab pertanyaan dari teman maupun guru. Hasil pengamatan terhadap kegiatan pembelajaran dapat dilihat dalam tabel berikut. 
Tabel 1

Pengamatan terhadap peserta didik

\begin{tabular}{clc}
\hline No & \multicolumn{1}{c}{ Indikator } & Jumlah \\
\hline 1. & Siswa memperhatikan penjelasan guru & $75,7 \%$ \\
2. & Siswa membaca sumber belajar & $68,7 \%$ \\
3. & Siswa mampu mempertahankan argumentasi & $67,9 \%$ \\
4. & Siswa bertanya instruksi maupun materi yang kurang dipahami & $65,6 \%$ \\
5. & Siswa memberi saran pada guru maupun teman & $48,4 \%$ \\
6. & Siswa mendengarkan percakapan atau diskusi kelompok & $72,6 \%$ \\
7. & Siswa mendengarkan penyajian materi yang diberikan guru & $57,0 \%$ \\
8. & Siswa mengerjakan tes individu & $50,7 \%$ \\
9. & Siswa aktif berdiskusi di dalam kelompok & $58,5 \%$ \\
10 & Siswa mengingat materi yang diberikan guru & $52,3 \%$ \\
11. & Siswa mampu membuat keputusan dalam diskusi kelompok & $60,1 \%$ \\
12. & Siswa berani menjawab pertanyaan guru secara lisan & $55,4 \%$ \\
13. & Siswa bersemangat mengikuti kegiatan pembelajaran & $66,4 \%$ \\
& $\quad$ Keaktifan Belajar Siswa & $\mathbf{6 1 , 4 8 \%}$ \\
\hline
\end{tabular}

Hasil belajar IPS menunjukkan persentase sebesar 50\% atau hanya 16 peserta didik yang memperoleh nilai di atas nilai Kriteria Ketuntasan Minimal (KKM) dengan rata-rata nilai 74,81\%. Hasil belajar IPS pada siklus 1 ini tergolong masih rendah karena peserta didik yang memiliki nilai di atas nilai Kriteria Ketuntasan Minimum (KKM) kurang dari 75\% dari 32 jumlah peserta didik. Presentase tersebut masih kurang dari standar yang ditetapkan oleh SMP Negeri 14 Surakarta yaitu minimal 75\% dari peserta didik tiap kelas memiliki nilai di atas nilai KKM

Tabel 2

Hasil tes pada siklus 1

\begin{tabular}{llrr}
\hline \multicolumn{1}{c}{ Kategori } & & Post-Test \\
\cline { 2 - 4 } & Frekuensi & \% \\
\hline Nilai $\geq 75$ & 16 & & $50 \%$ \\
Nilai $<75$ & 16 & & $50 \%$ \\
Jumlah & 32 & $\mathbf{7 4 , 8 1}$ & $100 \%$ \\
Rata-Rata & & $\mathbf{7 4}$ \\
\hline
\end{tabular}

Kegiatan refleksi dilakukan oleh peneliti bersama dengan guru dengan cara diskusi di ruang guru. Beberapa aspek yang belum berkembang menjadi perhatian dari peneliti terutama sebab-sebab belum berhasilnya perlakuan pada siklus 1 . hasil diskusi memutuskan untuk melakukan perlakuan dengan berbagai modifikasi dan 
penyesuaian. Kegiatan ini juga sekaligus dilanjutkan dengan perencanaan perlakuan yang akan diberikan pada siklus 2. Tindakan siklus 2 dilaksanakan sebanyak dua kali pertemuan. Pertemuan pertama dilaksanakan pada hari Kamis 11 Mei 2019 dan pertemuan kedua pada hari Selasa, 14 Mei 2019. Dengan materi "Masuknya Kebudayaan Islam di Indonesia” Dalam kegiatan pembelajaran siklus 2 tim peneliti mengupayakan berbagai inovasi dan modifikasi antara lain dengan tepuk tangan, yelyel, dan memberikan penguatan berupa pujian kepada peserta didik dan kelompoknya yang berhasil dengan baik.

Hasil pengamatan menunjukkan bahwa peserta didik sudah terbiasa dengan model pembelajaran yang digunakan sehingga kekompakan kelompok yang dibutuhkan telah terjalin dengan cukup baik. Sebagian besar anggota kelompok telah ikut aktif dalam diskusi, hanya beberapa orang yang tidak terlibat aktif. Ketika kuis diberikan, sebagian besar peserta didik mengerjakan secara individu, sehingga telah terjadi proses pendewasaan dan keaktifan sebagaimana skenario pembelajaran yang dirancang.

Tabel 3.

Hasil pengamatan aktivitas belajar siklus 2

\begin{tabular}{|c|c|c|}
\hline No. & Aspek yang diamati & Jumlah \\
\hline 1. & Peserta didik memperhatikan penjelasan guru & $78,1 \%$ \\
\hline 2. & Peserta didik membaca sumber belajar & $72,6 \%$ \\
\hline 3 . & Peserta didik mampu mempertahankan argumentasi & $70,3 \%$ \\
\hline 4 . & $\begin{array}{l}\text { Peserta didik mengajukan pertanyaan pada instruksi } \\
\text { maupun } \\
\text { materi yang kurang dipahami }\end{array}$ & $72,6 \%$ \\
\hline 5 . & Peserta didik memberi saran pada guru maupun teman & $65,6 \%$ \\
\hline 6. & $\begin{array}{l}\text { Peserta didik mendengarkan percakapan atau diskusi } \\
\text { kelompok }\end{array}$ & $75 \%$ \\
\hline 7 . & $\begin{array}{l}\text { Peserta didik mendengarkan penyajian materi yang } \\
\text { diberikan guru }\end{array}$ & $65,6 \%$ \\
\hline 8. & Peserta didik mengerjakan tes individu & $63,3 \%$ \\
\hline 9. & Peserta didik aktif berdiskusi di dalam kelompok & $64,8 \%$ \\
\hline 10 & Peserta didik mengingat materi yang diberikan guru & $68,8 \%$ \\
\hline 11. & $\begin{array}{l}\text { Peserta didik mampu membuat keputusan dalam diskusi } \\
\text { kelompok }\end{array}$ & $68,7 \%$ \\
\hline 12. & Peserta didik berani menjawab pertanyaan guru secara lisan & $64,8 \%$ \\
\hline 13. & $\begin{array}{l}\text { Peserta didik bersemangat mengikuti kegiatan pembelajaran } \\
\text { Keaktifan Belajar Peserta didik }\end{array}$ & $\begin{array}{l}73,4 \% \\
75 \%\end{array}$ \\
\hline
\end{tabular}


Hasil pengamatan pada siklus 2 dilakukan pada saat proses pembelajaran dimana guru memberikan penjelasan secara detail tentang model pembelajaran yang akan digunakan. Peserta didik terlihat dapat mengikuti langkah-langkah pembelajaran dengan baik. Motivasi yang diberikan guru kepada peserta didik sudah baik, dimana peserta didik yang terlihat lebih aktif dalam pembelajaran. Dari tabel 3 terlihat bahwa perhatian peserta didik terhadap kegiatan pembelajaran menjadi meningkat sebesar 78,1\%. Namun mereka belum mampu menuangkan ide-ide kritis dan kreatif dalam kegiatan kelompok maupun dalam kegiatan pleno di kelas dengan catatan $64,81 \%$.

Namun meski masih memiliki banyak kekurangan, implementasi model STAD menunjukkan presentase di atas 70\%. Persentase keaktifan peserta didik pada siklus 2 menunjukkan angka 75\%. Dalam kegiatan refleksi disepakati bahwa keaktifan belajar peserta didik sudah menunjukkan nilai baik atau telah memenuhi kriteria keberhasilan penelitian. Hasil belajar peserta didik pada siklus 2 juga menunjukkan kemajuan yang dapat yang signifikan. Untuk mengukur pencapaian hasil belajar IPS peneliti melakukan tes yang hasilnya telrihat dari tabel di bawah.

Tabel. 4

Hasil tes pada siklus 2

\begin{tabular}{|c|c|c|}
\hline \multirow[t]{2}{*}{ Kategori } & \multicolumn{2}{|c|}{ Post-Test } \\
\hline & Frekuensi & $\%$ \\
\hline Nilai $\geq 75$ & 29 & $91 \%$ \\
\hline Nilai < 75 & 3 & $9 \%$ \\
\hline Jumlah & 32 & $100 \%$ \\
\hline Rata-Rata & \multicolumn{2}{|c|}{83,53} \\
\hline
\end{tabular}

Hasil belajar IPS menunjukkan post- test dengan presentase sebesar 91\% yang berarti sebanyak 29 peserta didik yang memperoleh nilai di atas nilai KKM dengan rata-rata nilai 83,53. Hasil belajar IPS pada siklus 2 sudah tergolong baik karena peserta didik yang memiliki nilai di atas KKM sudah melebihi $75 \%$ dari 32 jumlah peserta didik. Presentase tersebut sudah sesuai dengan standar yang ditetapkan oleh SMP Negeri 14 Surakarta yaitu minimal 75\% dari peserta didik tiap kelas memiliki nilai di atas nilai KKM. Selain dilihat dari presentase tersebut hasil belajar sudah tergolong baik dapat dilihat dari rata-rata nilai yang menunjukkan di atas 75 atau di atas KKM. 
Penelitian pada siklus 2 dikatakan telah berhasil, hal ini dikarenakan data yang didapatkan telah memnuhi kriteria yang telah ditetapkan sebelumnya dengan rincian data sebagai berikut: keaktifan belajar peserta didik setelah adanya tindakan implementasi model pembelajaran kooperatif tipe STAD pada mata pelajaran IPS kelas VII D SMP Negeri 14 Surakarta pada siklus I dijelaskan pada masing-masing aspek yang diamati Berdasarkan tabel di atas diketahui keaktifan peserta didik kelas VII D pada mata pelajaran IPS pada siklus II memiliki presentase sebesar, kegiatan visual 78,1\% dan 72,6\%, kegiatan lisan 70,3\%, 72,6\% dan 65,6\% , kegiatan mendengarkan $75 \%$ dan $65.6 \%$, kegiatan menulis $63.3 \%$, kegiatan mental $64,8 \%$, 70,8\%, dan 68,7 \% kegiatan emosional 64,8\% dan 73,4\%. Data tersebut menunjukkan pada setiap aspek telah ada aspek yang menunjukkan presentase di atas $70 \%$ atau dari kesuluruhan aspek telah 7 aspek yang menunjukkan presentase 70\% dengan arti tingkat keaktifan belajar peserta didik sudah menunjukkan nilai baik.

Hasil penelitian menunjukkan bahwa model pembelajaran STAD mampu meningkatkan keaktifan belajar peserta didik. Isjoni (2012:51), menyebutkan student teams achievement division merupakan tipe pembelajaran kooperatif yang menekankan pada adanya aktivitas dan interaksi di kelas baik diantara guru dan peserta didik maupun anatara para peserta didik untuk saling memotivasi dan saling membantu dalam menguasai materi pembelajaran. Dalam hal ini dapat dilihat bahwa model pembelajaran kooperatif tipe STAD menuntut peserta didik untuk aktif, sehingga melalui langkah-langkah dalam pembelajaran dengan model tersebut dapat meningkatkan keaktifan peserta didik dalam belajar. Keberhasilan penelitian yang dilakukan juga diperkuat dengan teori Djamarah (2013: 107) yang menjelaskan bahwa dilihat dari segi proses, pembelajaran dikatakan berhasil dan berkualitas jika seluruhnya atau setidak tidaknya sebagian besar 70\% peserta didik terlibat aktif, baik fisik, mental, maupun sosial dalam proses pembelajaran.

Hasil penelitian menunjukkan bahwa perubahan keaktifan siswa terlihat Ketika guru menggunakan model STAD dalam pembelajaran IPS. Isjoni (2012:51), tipe STAD merupakan tipe pembelajaran kooperatif yang menekankan pada adanya aktivitas dan interaksi di kelas baik diantara guru dan peserta didik guna mencapai hasil belajar yang maksimal. Dalam hal ini dapat diketahui bahwa pembelajaran kooperatif tipe STAD merupakan model pembelajaran yang bertujuan untuk meningkatkan hasil belajar peserta didik. Berdasarkan hasil penelitian, rata-rata hasil belajar peserta didik mengalami peningkatan dari siklus 1 ke siklus 2 yaitu sebesar 8,72 atau dengan presentase sebesar $28,5 \%$. Pada siklus 2 peserta didik yang memiliki nilai diatas nilai 
KKM sudah melampaui batas minimal yaitu $75 \%$ dari jumlah peserta didik. Hal ini sudah sesuai dengan teori yang dikemukakan oleh Djamarah (2013: 107) menjelaskan bahwa dari segi prestasi dapat dikatakan berhasil jika adanya peningkatan dan sekurangnya $75 \%$ peserta didik dalam satu kelas mencapai KKM. Nilai peserta didik pada siklus II dengan rata-rata 83,53, menunjukkan bahwa nilai tersebut telah mencapai KKM yaitu $\geq 75$.

\section{Simpulan}

Upaya peningkatan keaktifan belajar dan hasil belajar IPS kelas VII D SMP Negeri 14 Surakarta menggunakan model pembelajaran kooperatif STAD dilakukan melalui langkah-langkah pembelajaran sebagai berikut: pembagian kelompok, menentukan skor awal, membangun kelompok, pemaparan materi, belajar kelompok, mengerjakan kuis, menghitung skor individu dan kelompok, merekognisi prestasi kelompok, dan mengembalikan hasil kuis, dengan menekankan diskusi kelompok, kecakapan individu, dan mengerjakan kuis. Langkahlangkah tersebut kemudian mengalami modifikasi dan adaptasi sesuai dengan kondisi dan situasi belajar di tempat subjek penelitian.

Keaktifan belajar dan hasil belajar IPS peserta didik mengalami peningkatan. Persentase keaktifan belajar peserta didik pada siklus I sebesar 61,48\% dan meningkat pada siklus II dengan persentase keaktifan belajar peserta didik sebesar 75,0\%. Hasil belajar peserta didik berdasarkan rata-rata hasil belajar peserta didik pada siklus I sebesar 74.81 dengan presentase ketuntasan sebesar 63\% dan meningkat pada siklus II dengan rata-rata hasil belajar sebesar 83.53 dengan presentase ketuntasan sebesar 91\%. Hasil capaian dari penelitian tindakan kelas memberikan gambaran bahwa penggunaan metode pembelajaran yang bervariasi merupakan kata kunci untuk meningkatkan kualitas pembelajaran. Penggunaan metode yang berbeda dari biasanya akan menimbulkan antusiasme peserta didik untuk terlibat secara aktif dalam kegiatan belajar.

Dalam melaksanakan pembelajaran IPS guru sebaiknya menggunakan model pembelajaran yang bervariasi sehingga dapat meningkatkan keaktifan dan hasil belajar peserta didik. Variasi model pembelajaran merupakan kunci untuk meningkatkan kualitas pembelajaran IPS di sekolah karena rancangan yang bervariasi dapat menarik perhatian siswa untuk terlibat secara aktif. Keterlibatan secara aktif merupakan aspek penting agar pembelajaran IPS lebih bermakna.

Untuk memfasilitasi pembelajaran IPS sebaiknya guru menerapkan model 
pembelajaran kooperatif tipe STAD dengan mengembangkan berbagai bentuk kegiatan dan penyajian. Menggunakan pembelajaran dalam bentuk berkelompok dapat memberi kesempatan lebih besar kepada peserta didik untuk menuangkan pendapat sehingga peserta didik dapat berperan aktif dalam pembelajaran. Untuk meningkatkan keaktifan belajar peserta didik, sebaiknya guru memberikan motivasi sebagai pengingat kepada peserta didik untuk sering bertanya dalam pembelajaran. Namun yang lebih penting lagi bagi guru IPS adalah mendesain pembelajaran IPS dengan inovatif, kreatif, dan bervariasi. Sebagus apapun metode pembelajaran bila digunakan terus menerus akan membosakan, sehingga kreativitas dan inovasi guru sangat penting.

\section{Referensi}

Djamarah, S., B. (2013). Strategi belajar mengajar. PT. Bineka Cipta

Habsiah, S., Effendi, R. \& Mulyadi, A. (2017). The effect of cooperative learning model of student team achievement division (STAD) type in attempt to improve student tolerance character. International Journal Pedagogy Social Studies, 2 (1), 115123. https://doi.org/10.17509/ijposs.V2I1.8668

Hanifah, E., N. \& Wulandari, T. (2018). Penggunaan metode card short untuk meningkatkan keaktifan peserta didik dalam pembelajaran IPS Kelas VIII E SMP Negeri 1 Majalengka, JIPSINDO, 5(1), 618o. https://doi.org/10.21831/jipsindo.v5I1.20184

Isjoni. (2012). Pembelajaran kooperatif: Meningkatkan kecerdasan komunikasi antar peserta didik. Pustaka Pelajar.

Kemmis, S., \& Taggart, R. (1999). The action research planner. Deakin University Press.

Miles, M. B., \& Huberman, M. A. (1994). An expanded sourcebook: Qualitative data analysis. Sage Publications

Milhani, Y. (2017). Keefektifan model pembelajaran students team achievement division dalam pembelajaran IPS di SMP Negeri 15 Yogyakarta, JIPSINDO, 4 (2), 101-128. https://doi.orG/10.21831/jipsindo.v4I2.17571

Nergney, R., F. \& Herbert, J., M. (2001). Foundations of education: The challenge of professional practice. Allyn \& Bacon.

Nurmayanti, D. N., Zahara, R., Lisnawati, C. (2014). Efektivitas penerapan model cooperative learning type student team's achievement division (STAD) untuk meningkatkan motivasi belajar siswa. Educare, 12(2), 1-8. 
Model student team achievement ... (Sumiyati)

Ornstein, A., C. \& Levis, D., U. (1989). Foundation of education. Houghton Mifflin Co.

Kementrian Pendidikan dan Kebudayaan. (2016). Permendikbud No 22 Tahun 2016 tentang Standar Proses Pendidikan Dasar dan Menengah pembelajaran.

Kementrian Pendidikan dan Kebudayaan. (2013). Permendikbud Nomor 64 Tahun 2013 tentang standar isi

Slavin, R., E. (2011). Cooperative learning: Teori riset dan praktik. (Terjemahan Narulita Yusron). Nusa Media.

Sudrajat, Supardi, \& Milhani, Y. (2020). Humanistic learning of social studies at junior high school of Budi Mulia 2 Yogyakarta, Indonesia. International Journal of Education, 12 (1), 46-55. doi:10.5296/ijev12i1.16066.

Supardi. (2013). Dasar-dasar ilmu sosial. Penerbit Ombak.

Suparmini, Sudrajat \& Wibowo, S. (2015). Strategi cooperative learning sebagai peningkatan kualitas pembelajaran IPS di SMP. JIPSINDO, 2(2), 12O-142. https://doi.org/10.21831/jipsindo.V2I2.7778

Syamsu, F., N; Rahmawati, I; \& Suyitno (2019). Keefektifan model pembelajaran STAD terhadap hasil belajar Matematika materi bangun ruang. International Journal of Elementary Education, 3(3), 344-350.

Tilaar, H.A.R \& Nugroho, R. (2008). Kebijakan pendidikan. Pustaka Pelajar. 